\title{
COMPOUNDING WORDS ; WORDS FORMATION IN REPUBLIKA NEWSPAPERS
}

\author{
Eripuddin, Liana Fuji Lestari \\ eripuddin85@gmail.com,liana.ln757@gmail.com \\ Universitas of Pasir Pengaraian
}

\begin{abstract}
This study investigated words formation that found in the republika newspaper. The research was a descriptive qualitative research design . The object of this research was headline of Republika Newspaper. The instrumentation of the reserach was documentation. The data were consisted of 96 data The data were analyzed by using the theory of word formation (O' Grady, 1996) The results of this research shown that 70 data were classified as endocentric compound and transparent meaning and 26 data were categorized in exocentric compound and opaque meaning. Transparent meant that the meanings of the words could be predicted from the each of the word. Opaque meant that the meaning of words could not predicted from the each of word.
\end{abstract}

Keywords :Word Formation, Compounding, Newspaper.

\section{INTRODUCTION}

Language is a communication tool used by humans to interact with one and another in the form of sound symbols and sign. According to Kushartanti et al (2009:3) said that language is a sound system used by society group to collaborate, communicate and to identify themselves. Nowadays, the existence of language has been developed to be the object of study. Students can learn much more detail about language scientifically through linguistics. One of linguistics aspects is concerned with morphology.

Morphology is a study of the words of language and inflection use form new words. One of morphology scopes is a word formation. The word formation is a creation of the new word. There are process word formation, one of them is compounding. Compounding is one of word formation which is very interesting since it can create a new word whose meaning.

A compound is a new word created by the word formation process of compounding. According to O'grady \& Guzman (1996:143) states that compounding is a morphological process in human language the combination of lexical categories (nouns, adjectives, verbs, or prepositions) to create a large word. The combination of some that word creates 
a meaning of a word which is easier to comprehend, for example, eyeglasses and post office. But there are also some of them which create a new meaning. For example, pigtail (rambut kuncir), the meaning of pigtail itself is not the real meaning that is the tail of a pig.

Compound words are written in different ways. The writing of two words compound in English is not consistent. Then, the writing of hyphenated word is used when a compound has been newly created or not widely used. The last is writing compound in one word. It is used to compound words which have gained a certain currency or permanence.

Compound words are not a simple as it seems. One of example the compound word found in a headline. However, it is showns the important meaning which is expressed by the writer to help the readers to understand the headline. The function of compound words in a headline is to understand a context, because there are many difficulties in understanding the context, like reading a headline of the online newspaper, the reader does not know the word formation of headline

\section{REVIEW OF THE RELATED LITERATURE}

Morphology is an analysis of word structure. According to O'grady \& Guzman (1996:132), morphology is a system of categories and rules involved in word formation and interpretation. In other words, the study of word formation, including the ways new words are coined in the languages of the world, and the way forms of words are varied depending on how they are used in sentences. It means that morphology is a study of internal structure of words, with the form of lexemes, and with the in which lexemes are formed word formation.

According to Cartairs (2002:59) says compounds are words formed by combining roots, and the much smaller category of phrasal word, that is items that have the internal structure of pharases but function syntactically as word. The last Katamba mentions that compound word is a word made up of at least two bases which can occur elsewhere as independent word (1993:291).

Moreover, types of compound words are Endocentric and Exocentric compound. Endocentric compound is a compound which the meaning can be denoted its head. O'grady and Guzman (1996: 154) endocentrix is a compound that identifies the general class which the meaning of entire word belongs. Such as dog food is a type of food. And a cave man is a type of man. While, exocentric is is compound which the meaning does not follow from its part' meaning. O'grady and Guzman (1996: 154) says exocentric is a compound does not follow from the meaning of its parts in this way.

The meaning is massage contains in a word. Ullman (1972: 81) says every compound contains words which are arbitary and opaque, without any connection between sound and sanse, and other which are at least to some degree motivated and transparent. Based on theory Ullman the researcher classiffy the transparent meaning and opaque meaning.

\section{METHOD}

The design of this research is a descriptive qualitative research. Arikunto (2010) says that descriptive research is the researcher have purpose to accurate the situation, condition, and 
other which is said, the result is explain in report of the researcher. It means qualitative research describes the way things is bases on the fact and stated instatement. The object of the research is compound words used in headline of the Republika newspaper edition from of $2^{\text {nd }}$ until $30^{\text {th }}$ of April 2019. The data is collected by browsing internet. The main source of the data in this Republika newspaper online. The Technique of collecting the data were, downloading Republika newspaper from the internet, reading headline of the Republika newspaper, and analysis the headline of the Republika newspaper using O'Grady theory.

\section{FINDINGS AND DISCUSSION}

The headline of the Republika Newspaper as source in this research. The researcher analyzed compound words used in headline of the Republika newspaper. The data was analyzed to find out types and meaning of compound words of the Republika Newspaper. The researcher described them with the following table.

Table 1. Types of Compound Words

\begin{tabular}{c|l|c}
\hline No & Kind of Compound & Total \\
\hline 1 & $\begin{array}{l}\text { Endocentric } \\
\text { Compound }\end{array}$ & 70 \\
\hline 2 & Exocentric compound & 26 \\
\hline
\end{tabular}

The table above shows that compound word that used in headline of the Republika as much as 96 data consists 70 data included in the endocentric compound categories and 26 data were exocentric compound categories. The researcher described them with following table. One of them compound consisted endocentric was campaign day (N) consisted of two lexemes, Campaign $(\mathrm{N})$ and Day $(\mathrm{N})$. Based on
Oxford Dictionary, the meaning of Campaign $(N)$ formally had a constituted political or social group that work in an organized and active way toward a particular goal. Then, the meaning of day $(\mathrm{N})$ as a period of twenty-four hours as a unit of time, corresponding to a rotation of the earth on its axis. The campound word campaign day $(\mathrm{N})$ had a meaning of day related to politics to influence the decision making process of the voters. The meaning of campaign day can be identified from the head which is day. This compound word was considered as an endocentric because the meaning could identified from the head or transparent. The data consited exocentric compound was baby blues $(\mathrm{N})$ consisted of two lexemes, baby $(\mathrm{N})$ and blues $(\mathrm{N})$. The word baby was children of very young humans or animals. The word blues was kind one of color. Thus, the meaning of baby blues was not blues, but it was a condition that usually occurs in mothers after childbirth. Sadness, anxiety, and finally stress. Baby blues were an exocentric compound because the meaning could identified from the head.

Table 2. Meaning of Compound Words

\begin{tabular}{c|c|c}
\hline No & Meaning & Total \\
\hline 1 & Transparent meaning & 70 \\
\hline 2 & Opaque mesning & 26 \\
\hline
\end{tabular}

The table shows that the result transparent meaning and opaque meaning. The transparent meaning are 70 data for example airfares. Airfares is a type of fares. Thus friendship is not a type ship. So it catagorized as opaque. Based on the research finding above, the researcher found some types of compound words and analyzed of the meaning. The result of this research was not of all headline of newspaper had 
compound words. Total headline of the Republika Newspaper were 132 headline. There was 70 found endocentric compound, 26 found exocentric compound, and 36 was not of found compound word in headline of the Republika Newspaper.

\section{CONCLUSION AND SUGGESTION}

\section{Conclusion}

Based on the analysis and discussion, the researcher has analyzed the types and the meanings of compound words on headline in online newspaper published from $2^{\text {nd }}$ until $30^{\text {th }}$ of April 2019 of the English Republika.. The researcher found types and meaning compound words. There were 96 compound words found in the headline, and 36 compound words not found in the headline. the types of compound word in headline of the Republika newspaper were: first endocentric compound was found 70 data, and second exocentric compound was found 26 data. The meaning transparent was found 70 data, and opeque was found 26 data. The total compound word in headline 96 data.

\section{Suggestion}

Based on the conclusion explained in the previous chapter, there are some suggestions that can be useful for next researcher, readers and lectures.

\section{REFERENCE}

Arikunto, S. 2010. Procedure Penelitian. Yogyakarta: Rinka Cipta.Widoyoko, Eko. 2012. Teknik Penyusunan Instrument Penelitian. Yogyakarta. Pustaka Pelajar.
Cahyanti, Dwi Ririn. 2016. Compound Words Used In Stephenie Meyer's Twilight. Palangka Raya. MA Hidayatul Insan Palangka Ray.

Carstairs, Andrew. 2002. English Morphology: Word And Their Structure. Skotlandia: Edinburgh Unversity Press.

Crane, Edward Yeager, Randal L Whitmen. 1994. An Introduction To Linguistics. Little, Brown And Company: Boston Toronto.

Crystal, David. 1987. The Cambridge Encyclopedia of Language. Newyork:Cambridge University Press.

Donal, Andri. 2015. Students' Reading Interest A Case Study at Fkip of The University of Pasir Pengaraian. University of Pasir Pengaraian.

Erripudin. 2012. The Use of Domino Game inTeaching Word wit Suffix and Prefix at SMAN 1 Rambah Hilir. University of Pasir Pengaraian.

Hadiati. Chusni. 2014. A Morphological Analysis of English Compound Word Tolstoy's God Sees The Truth, But Waits. Vol.1 No. 2 Juli 2014.

Katamba, Francis. 1993. Morphology. London: The Micmillan Pres Ltd.

Kushartanti et al. 2009. Pesona Bahasa: Langkah Awal Memahami Lingustik. Jakarta: Gramedia Pustaka Utama.

Lieber, Rochelle. 1997. Introducing Morphology. New York: Cambrid Unversity Press. 
Noamianty, Denisa Sheilla. 2016. An Analysis Compound Words on Culinary Terms in Masterchef U.S Season 7 (2016). Jakarta. English Letters Dapartement, Faculty of Letters an Humanities, University Syarif Hidayatullah.

O'Grady, William and Guzman. 1996. Contemporary Linguistics: An Introduction. United Kingdom: Longman.

Rahadiyanti, I.D.A Paramatiti. 2017. Compound Words in Political Articles of Strategic Review Magazine. Yogyakarta. English Letters, University Sanata Dharma Yogyakarta.

Richards, J. C. and Renadya W.A. 2006. Methodology in Language Teaching. Cambridge: Cambridge Unversity Press.

Riduwan and Sunarto. 2012. Pengantar Statistik untuk Penelitian Sosial Ekonomi, Komunikasi dan Bisnis. Bandung: Alfabeta.

Rumiyati, Arum. 2015. A Morphological Analysis of Compound Words Used in Novel "The Single Girl's To-DoList" By Lindsey Kelk. Surakarta. English Dapertement, University Muhammadiyah Surakarta.

Ullmann, Stephen. 1972. Semantics an Introduction to the Science of Meaning. Great Britain: Butler and Tanner Ltd.

Van Dijk, T. A. 1988. News as Discourse. Hillsdale: Lawrence Erlbaum Associates. 
Balnk Page 